\title{
REFLECTIONS
}

\section{Boy Scouts for Henry}

Richard E. Allen, MD, MPH

St Mark's Family Medicine, Salt Lake City, Utah
Conflicts of interest: none reported

\section{CORRESPONDING AUTHOR}

Richard E. Allen, MD, MPH St Mark's Family Medicine Utah HealthCare Institute 1250 East 3900 S, Suite 260 Salt Lake City, UT 84124 rallen@utahhealthcare.org

\begin{abstract}
"Can we do anything for you?" The question was embarrassing. Henry had been poked and prodded and preserved far beyond his wishes. In a medical system that scorns comfort care, a resident physician is troubled by the case of an elderly man with poor quality of life. An awkward attempt at a Boy Scout service project emphasizes how poorly we comfort the terminally ill despite modern technology and interventionalism.
\end{abstract}

Ann Fam Med 2006;4:79-80. DOI: 10.1370/afm.373.

"Mr Kormos, you're going to die today."

It was his second hospital admission for pneumonia in 2 months. After nearly 80 years without seeing a doctor, Henry Kormos was again forced by dyspnea to enter my emergency department. He stopped shaking his head and looked up, squinting with one eye and doubting what he'd just heard.

"You're going to die today unless you let me help you," I finished saying. This time there was no mistaking my words. His face twisted in a mix of anger and confusion. He was nearly tied to the bed rails by intravenous lines and nasogastric tubing, and desperately dependent on the large plastic oxygen mask that sustained his labored breathing. His chest was bare and moving rapidly, the ribs forcefully sucking in each breath. Navy tattoos were dark and blurry on his arms, now covered in sweat. A tiny cockroach crawled out of his jeans pocket and onto his belly.

At that moment Mr Kormos wanted nothing more than to kick me, drop all the tubes, and get out of there. I could see in his wrenched face what I had seen before: disgust for modern medicine, but reliance on it for life. I felt unable to share with him my own reservations about interventional medicine. As a second-year resident, I would be laughed to scorn had I recommended comfort measures only.

We had talked through the consent form before. He knew what I needed to do and finally nodded his head once, then dropped his arms and closed his eyes.

The nurse helped me sit him upright, and I performed a thoracentesis to relieve his rapid breathing. Modern medicine triumphed over stubborn Mr Kormos.

The next morning, I introduced him to the medicine team and briefly explained his history. He appeared comfortable now as the crowd of white-coated observers looked in. They debated the merits of computed tomography, bronchoscopy, or both while awaiting cytologic results from the pleural fluid. A chest radiograph showed a fist-sized tumor that filled his right hilum. No doubt the tumor was causing postobstructive pneumonia and would require resection or radiation.

An hour later, I got a call from the nurse. "Your man wants out of here," she said. "He's pulled his IV, and he's stripping his jammies off right now." I ran to the floor.

I was tempted to discharge him with a prescription for oral antibiotics and home oxygen. That option was never mentioned on medicine rounds. 
No one would suggest giving in to the thing-the cancer or whatever else it was. We are trained instead to fight it at all costs.

I wondered how quickly I could arrange a hospice evaluation, but I had been told they would not come without a pathologically confirmed cancer diagnosis. My cantankerous old friend had no choice but to be subjected to the ways of contemporary hospitalization. He might have stayed home to die, but unfortunately, suffocation is intolerable and brings even the most stubborn of men to beg for our help.

He was struggling to put his pants on as I entered the room. A thin, greasy-haired man stood toward the back. His son, I presumed.

"Mr Kormos, you're very sick," I said, trying to simplify my approach.

"He can't go home," the son said. Henry's son had dumped him on our doorstep to begin with.

"I ain't staying in this place another minute," $\mathrm{Mr}$ Kormos said, then paused to hold the mask to his face and force in several breaths.

"Mr Kormos, you have a tumor." I turned to his son, "There's a huge mass in his lungs, and it might be cancer."

"Tumor my eye!" Henry emphatically shook his head.

"Dad, you've got cancer. You've got to stay," emphasized the son. But the words tumor and cancer didn't have the shock effect that I'd hoped for.

Suddenly, Henry collapsed. "Nurse!" I called, catching Henry's fall and pushing him on to the bed. I cranked the oxygen and held the mask tightly to his face. "Let's tube him, and get 2 new IVs going ...." The son stood silently as we worked to save his father's life.

In a week of mechanical ventilation, Mr Kormos continued to fight every needle, scan, and catheter. Hospice care was forgotten as we pushed "a finger or tube in every orifice." Although my name was on the chart, the matter seemed out of my hands as he underwent bronchoscopy, endoscopy, feeding tube insertion, and more. One morning I saw a note with a signature I didn't recognize: "Open biopsy warranted," it read. The new thoracic surgeon in town. "Warranted!" Not "necessary" or "important," but "warranted." And no doubt paid for by Medicare.

It was out of my hands, and Henry's, as the son was convinced by one doctor after another that it was noble to do all these things. To "fight this thing to the bitter end," I could imagine them saying. Like a war with a mortal enemy or a pursuit of a dangerous criminal.

In 2 months, Henry had improved somewhat and was in stable condition in a nursing home. Modern medicine triumphed once again. One Sunday morning, I took a group of Boy Scouts to visit him. My neighbor said the boys needed a service project, and he asked whether I would take them to visit someone.
Henry was propped up in the bed, naked except for a diaper. I pictured him fighting off the staff as they tried to bathe and clothe him. He looked up to recognize me, like old friends who'd survived the war together. I knew he wouldn't mind the boys coming in, just like medicine rounds in the intensive care unit They all looked sharp in their tan uniforms. One carried a plate of cookies that my wife had sent along.

"These are my scouts," I spoke loudly for him to hear. He nodded at them, still sucking for air with each inspiration. A portable oxygen machine breathed loudly in the otherwise quiet room. Henry brushed off flies as they landed on his moist skin. He was unkempt, and the room was filthy. I wondered whether he liked it that way or whether the cleaning staff just didn't dare bother old Mr Kormos.

"Can we do anything for you?" I asked. The question was embarrassing. I was embarrassed to be there and to have the boys. I showed them a man who badly needed our charity, but all we had was a plate of cookies. There was cleaning and bathing and feeding to be done. There was probably a home left unoccupied and decrepit. And there was the labor of breathing and the wasting. I felt incapable of offering any real service to him. Only a visit to lessen his loneliness.

Moments passed. "Well, we just wanted to make a visit," I said, to indicate our departure. I paused at the door and let the boys go into the hallway. Then I walked back in alone and sat at the end of Henry's bed.

"I didn't mean to put you through this, Mr Kormos. I wish you could have gone home," I said. Henry looked at me without speaking. He had not spoken in a month. He glared earnestly into my eyes. He blinked frequently and sucked intently on the air mask.

Henry died later that month. I shared the news with my wife and shed a tear of relief. Henry was only the first of several terminally ill patients I have known. To assist their death is criminal, but to prolong a life with no quality may be equally wrong.

Sometimes our patients need help and permission to pass on, a peaceful death uninterrupted by diagnostics and rescue procedures. I think of this when I picture Henry. I daydream of a thin old man, his clean bare chest now breathing comfortably. A smile is on his face. He reminds me that a doctor who cares is the greatest success of modern medicine.

To read or post commentaries in response to this article, see it online at http://www.annfammed.org/cgi/content/full/4/1/79.

Key words: Medical decision making; palliative care; end-of-life care; terminally ill; empathy; practice of medicine/health care

Submitted January 10, 2005; submitted, revised, May 3, 2005; accepted May 31, 2005. 